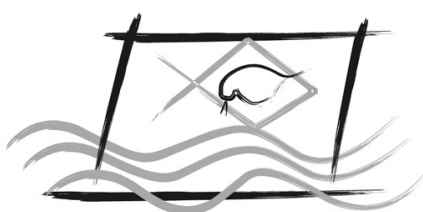

ECOTOX - BRASIL

\title{
The use of biomarkers to study the effects of the mixture of diuron and hexazinone on small and large $O$. niloticus
}

\author{
Franco-Bernardes, M.F.; Maschio, L.R.; Azeredo-Oliveira, M.T.V. \& Almeida, E.A. \\ Universidade Estadual Paulista Júlio de Mesquita Filho. Rua Cristóvão Colombo, 2265. 15054-000. São José do Rio Preto, SP. Brazil.
}

(Received February 08, 2015; Accept November 10, 2015)

\begin{abstract}
Pesticides have made possible a safer and plentiful supply of food; however, the ultimate sink for many of these contaminants is the aquatic environment. We analyzed the commercial mixture Velpar $\mathrm{K} \otimes \mathrm{WG}$, which is composed of the pesticides diuron $(46.8 \% \mathrm{~m} / \mathrm{m})$ and hexazinone $(13.2 \% \mathrm{~m} / \mathrm{m})$, as well as inert ingredients $(40.0 \% \mathrm{~m} / \mathrm{m})$. The present study aimed to evaluate the effects of the herbicide mixture on Oreochromis niloticus of different sizes. To this end, we analyzed biomarkers in small and large $O$. niloticus exposed to a mixture of herbicides at 125,250 and $500 \mathrm{ug} \mathrm{L}^{-1}$ for $72 \mathrm{~h}$. EROD increased activity in small fish exposed to the herbicide mixture at 250 and $500 \mathrm{ug} \mathrm{L}^{-1}$. The GST activity and levels of the antioxidant enzymes GPx and CAT remained the same in the treated fish, compared with the control. The level of the antioxidant enzyme SOD measured in the fish gills was changed in animals exposed to the herbicide mixture at $250 \mathrm{ug} \mathrm{L}^{-1}$. MDA analysis did not show lipid peroxidation. The comet assay evidenced widespread DNA damage, but the micronucleus test did not show mutagenicity. Hepatosomatic (HSI) analysis did not indicate any alterations in liver morphology. The biomarkers response in the fish depended on the size of the individuals.
\end{abstract}

Keywords: biomarkers; diuron; environmental toxicology; hexazinone.

\section{INTRODUCTION}

Herbicides play a crucial role in weed control, which is very important for improving agricultural production and yield. However, the excessive use of these substances may impact non-target organisms, especially aquatic fauna and flora and their environment (Nwani et al., 2011).

In Brazil, herbicides are the most used pesticide in agriculture, constituting $59 \%$ of all the classes of pesticides used in the agricultural sector, particularly in the soybean, corn, and sugarcane crops (Bortoletto et al., 2009; Alves et al., 2012). In 2011, herbicide delivery reached 403,600 tons, representing an increase of $44 \%$ as compared with the 279,200 tons recorded in 2006 (Freitas Jr, 2012).

To control weeds in sugarcane cultures, a sustainable source of ethanol fuel, a pre- and post-emergent herbicide consisting of a mixture of diuron and hexazinone is widely used (Bicalho et al., 2010). The commercial mixture Velpar
$\mathrm{K} \circledast \mathrm{WG}$, composed of diuron $\left(46.8 \% \mathrm{~m} / \mathrm{m}\right.$, or $\left.468 \mathrm{~g} \mathrm{Kg}^{-1}\right)$, hexazinone $\left(13.2 \% \mathrm{~m} / \mathrm{m}\right.$, or $\left.132 \mathrm{~g} \mathrm{Kg}^{-1}\right)$, and inert ingredients $\left(40.0 \% \mathrm{~m} / \mathrm{m}\right.$, or $\left.400 \mathrm{~g} \mathrm{Kg}^{-1}\right)$, is routinely applied in agriculture and introduced into the environment.

Diuron belongs to the group of substituted ureas, and hexazinone belongs to the group of triazinones. Both compounds act by inhibiting the photosystem II of photosynthesis (Mei et al., 2012). Studies have shown that herbicides displaying this mode of action in plants (e.g., atrazine, diuron, and simazine) are highly mobile and can end up in stream networks (Lewis et al., 2009). Moreover, phenylurea derivatives are among the most widely used herbicides in agriculture (Barbash et al., 2001). However, removing these herbicides from the environment takes weeks, or even months (Mackay et al., 1997; Benitez et al., 2006).

Diuron (3-(3,4-dichlorophenyl)-1,1-dimethylurea) is a non-ionic compound with moderate water solubility about $36-42 \mathrm{mg} \mathrm{L}^{-1}$ at $20-25^{\circ} \mathrm{C}$ (Cabrera et al., 2010). This

*Corresponding author: Mariana Franco-Bernardes; e-mail: marianaffranco@yahoo.com.br 
herbicide persists in the environment, and its breakdown in ground and surface waters is extremely slow (Madhum et al., 1987; Abass et al., 2007). Hexazinone (3-cyclohexyl-6(dimethylamino)-1-methyl-1,3,5-triazine-2,4 (1H, 3H)-dione) tends not to undergo hydrolysis or photolysis, so it can persist in aquatic systems (Mei et al., 2012). This herbicide is highly water soluble $\left(33 \mathrm{~g} \mathrm{~L}^{-1}\right.$ at $\left.25{ }^{\circ} \mathrm{C}\right)$ and significantly mobile in soil, so it can potentially leach into ground water and run off into surface water (Mei et al., 2012; Wang et al., 2005).

Regarding the concentrations found in the environment, in canals of south Florida, United States, $76 \mathrm{ug} \mathrm{L}^{-1}$ of diuron and $4.5 \mathrm{ug} \mathrm{\textrm {L } ^ { - 1 }}$ of hexazinone were found in surface waters (Miles \& Pfeuffer, 1996). Besides, Lewis et al. (2009) analyzed water samples collected from river and creek sites in three geographical regions of the Great Barrier Reef catchment area (Australia). Sampling sites were selected based on land use in the upstream catchment area, including sugar cane cultivation (areas with $>10 \%$ sugar cane). In these sites, it was found diuron at concentrations up to $20 \mathrm{ug} \mathrm{L}^{-1}$ and hexazinone at concentrations up to $5 \mathrm{ug} \mathrm{\textrm {L } ^ { - 1 }}$.

The effects of the herbicides diuron and hexazinone in target organisms are already known, but given that they reach the aquatic environment after their application in agriculture, it is important to study the effect that these herbicides can cause in non-target animals, such as fish. Also, bearing in mind that agriculture uses commercial mixtures, not the pure pesticide, tests with the most commonly applied commercial mixtures are crucial to understanding the real impacts in the environment.

Fish serve as a good bioindicator for assessing environmental pollution: they are directly exposed to chemicals and mutagens resulting from agricultural production via surface runoff, or indirectly exposed to contaminants through the food chain of the ecosystem (Nwani, 2010). Nile Tilapia (Oreochromis niloticus) is a teleost fish that is distributed worldwide. This fish can function as a model for conducting toxicological studies and assessing environmental pollution (Min \& Kang 2008).

To determine whether these herbicides affect nontarget organisms, analysis of changes in enzyme activities (biotransformation and antioxidant enzymes) and lipid peroxidation offers a rapid means of assessing the toxic impact of pesticides on these organisms (Altinok et al., 2012). A wide range of biomarker assays, such as the micronucleus test and the comet assay, can also be used to monitor the effects of environmental pollutants (Çavas \& Könen, 2007). As a complement to the micronucleus test, many authors examine whether morphological changes - known as erythrocytic nuclear abnormalities (ENAs) - occur in the erythrocyte nucleus, as these changes are indicators of genotoxicity (Ayllon \& Garcia-Vazquez, 2001; Cavalcante et al., 2008). Morphological parameters, such as hepatosomatic indices (HSI), also help to evaluate the effects of xenobiotics.

Given that biomarker responses can vary significantly according to the size of the animal (Peixoto \& Santos, 2009), a factor that can indicate differences in the organism's susceptibility to the pollutant, the present study uses Nile Tilapias with differences in body length and weight in order to analyze the biomarker responses according to the animal's size.

This study aimed to investigate the biochemical and genetic effects of increasing concentrations of diuron and hexazinone, in the form of the commercial mixture Velpar $\mathrm{K}{ }^{\circledR} \mathrm{WG}$, on Nile tilapia of different sizes. To this end, we exposed the animals to the commercial herbicide mixture at concentrations of 125,250 , and $500 \mathrm{ug} \mathrm{L}^{-1}$ for $72 \mathrm{~h}$. We then analyzed the activities of EROD (in the liver) and GST, SOD, CAT, and GPx, as well as the levels of lipid peroxidation (in the liver and gills) in O. niloticus. We also evaluated genome damage on the erythrocytes of the animals, through the micronucleus test and the comet assay. We hypothesize that this herbicide can induce metabolic and genetic alterations in Nile tilapias, and that smaller fish are more susceptible to the effects of diuron and hexazinone than larger fish.

\section{MATERIAL AND METHODS}

\section{Chemicals}

The reagents were purchased from Sigma Chemical. In our study, the herbicide was tested in the form of the complex commercial mixture, as this form is routinely applied in agriculture and introduced into the environment. The commercial mixture of diuron and hexazinone (Velpar $\mathrm{K}{ }^{\circledR} \mathrm{WG}$ ), composed of $46.8 \% \mathrm{~m} / \mathrm{m}$ (or $468 \mathrm{~g} \mathrm{Kg}^{-1}$ ) of 3-(3,4-dichlorophenyl)-1,1-dimethylurea (diuron), 13.2\% $\mathrm{m} / \mathrm{m}$ (or $132 \mathrm{~g} \mathrm{Kg}^{-1}$ ) of 3-cyclohexyl-6-dimethylamino-1methyl-1,3,5-triazine-2,4 $(1 \mathrm{H}, 3 \mathrm{H})$-dione (hexazinone), and $40.0 \% \mathrm{~m} / \mathrm{m}$ (or $400 \mathrm{~g} \mathrm{Kg}^{-1}$ ) of other ingredients, was selected for the study. We analyzed the concentrations of 125, 250 and $500 \mathrm{ug} \mathrm{L}^{-1}$ of the commercial mixture, which is equivalent to $58.5,117$, and $234 \mathrm{ug} \mathrm{L^{-1 }}$ of diuron and 16.5, 33, and $66 \mathrm{ug} \mathrm{L}^{-1}$ of hexazinone, respectively.

\section{Animals and experimental design}

Adult Nile tilapia (O. niloticus), of both sexes, were obtained from the aquaculture center of Universidade Estadual Paulista (State University of São Paulo - UNESP), of Jaboticabal Campus, São Paulo, Brazil, and transferred to the animal ecology laboratory of the same University, São José do Rio Preto Campus, São Paulo, Brazil. The fish where kept in tanks for at least one week before the experiment, to acclimatize. There were a total of 48 fish: 24 small (mean length $10.73 \pm 1.72 \mathrm{~cm}$, mean weight $43.00 \pm 13.42 \mathrm{~g}$ ) and 24 large (mean length $18.76 \pm 2.15 \mathrm{~cm}$, mean weight $182.51 \pm$ $58.39 \mathrm{~g}$ ), as shown in Figure 1.

For each size of fish tested in this study (small and large), a control group and three experimental groups were assayed, with a total of eight groups. A different concentration of the herbicide mixture was used in each experimental group, namely 125,250 , and $500 \mathrm{ug} \mathrm{L}^{-1}$, corresponding to diuron 

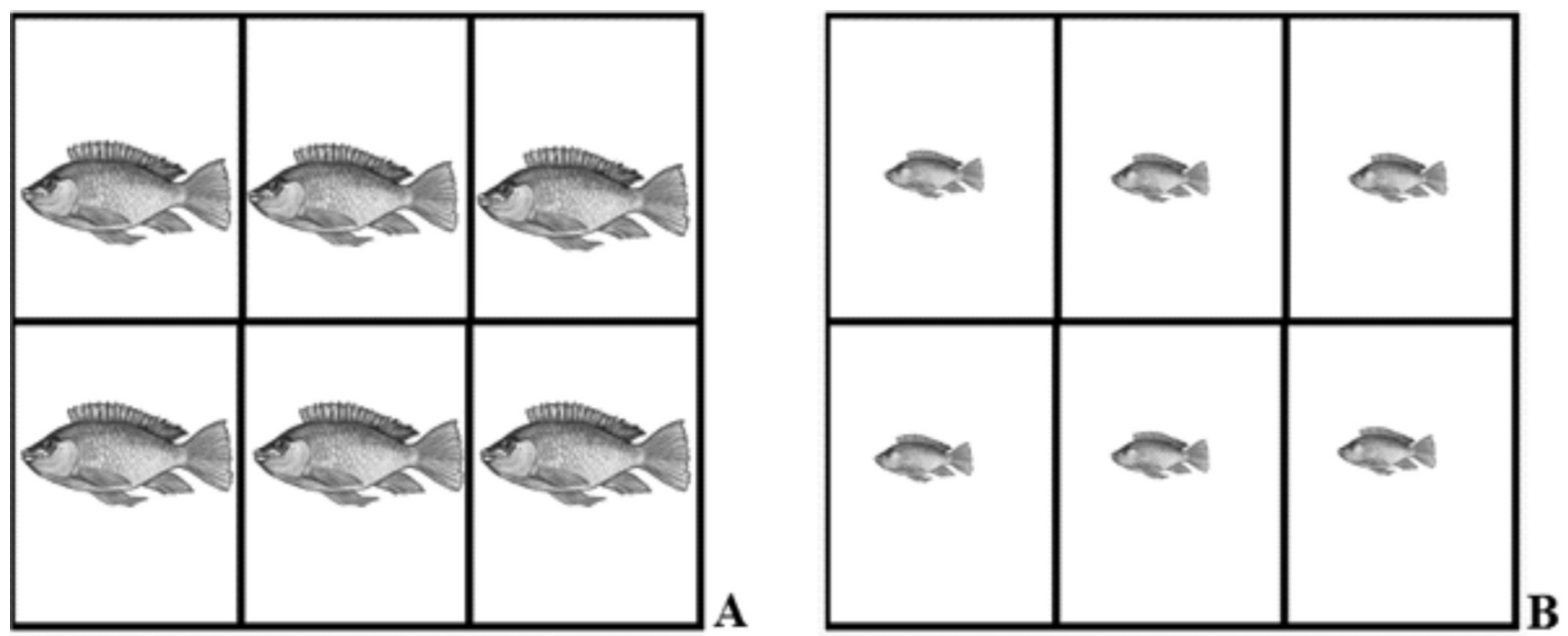

Fig 1. Figure of the experiment showing the compartments. A: Large fish (mean length $18.76 \pm 2.15 \mathrm{~cm}$, mean weight $182.51 \pm 58.39 \mathrm{~g}$ ). B: Small fish (mean length $10.73 \pm 1.72 \mathrm{~cm}$, mean weight $43.00 \pm 13.42 \mathrm{~g}$ )

concentrations of $58.5,117$, and $234 \mathrm{ug} \mathrm{L}^{-1}$ and hexazinone concentrations of $16.5,33$ and $66 \mathrm{ug} \mathrm{L}^{-1}$ respectively. The concentration of $500 \mathrm{ug} \mathrm{L}^{-1}$ corresponded to a $1000 \mathrm{x}$ dilution of the solution recommended for use in agriculture, therefore the amounts used in the present study are comparable to those found in the environment, as shown by Lewis et al. (2009) and Miles \& Pfeuffer (1996).

For the experiment, eight $100 \mathrm{~L}$-capacity aquaria were used. Each aquarium had six $17 \mathrm{~L}$ compartments. Each compartment contained only one fish, with a total of six fish per group. Having isolated each fish in its compartment, we were able to guarantee the occurrence of replicates with $n=6$.

The aquaria were kept under constant aeration and temperature. No food was supplied to the fish during the experiment. The animals were exposed to the herbicide mixtures for $72 \mathrm{~h}$; after this period, they were anesthetized with benzocaine; the liver, gills and samples of blood were removed. The liver and gills were frozen at $-80^{\circ} \mathrm{C}$ for subsequent biochemical analysis. With the blood, histological slides were made for micronucleus test and comet assay in the same day.

\section{Preparation of samples for biochemical analysis}

To analyze the enzymes EROD, GST, SOD, GPx, and CAT, the tissues (liver and gills) were homogenized (1:4 weight:volume) in Tris-HCl $20 \mathrm{mM}, \mathrm{pH} 7.5$, containing sucrose $0.5 \mathrm{M}$, etylenediamine tetraacetic acid (EDTA) $1 \mathrm{mM}$, dithiothreitol (DTT) $1 \mathrm{mM}$, and $\mathrm{KCl} 0.15 \mathrm{M}$ as well as protease inhibitor phenylmethylsulfonyl fluoride (PMSF) $1 \mathrm{mM}$. The homogenate was centrifuged at $10,000 \mathrm{~g}$ for $30 \mathrm{~min}$, at $4{ }^{\circ} \mathrm{C}$, and the resulting supernatants were centrifuged at $50,000 \mathrm{~g}$ for $60 \mathrm{~min}$, at $4{ }^{\circ} \mathrm{C}$. The supernatant obtained after the second centrifugation was used to analyze GST, SOD, GPx, and CAT. The pellet of the liver samples was re-suspended in $100 \mathrm{~mL}$ of Tris- $\mathrm{HCl} 0.1 \mathrm{M}, \mathrm{pH}$ 7.5, containing EDTA $1 \mathrm{mM}$, DTT 1 $\mathrm{mM}$ and $\mathrm{KCl} 0.1 \mathrm{M}$ and used to analyze EROD activity. The prepared samples could then be aliquoted for later analysis. For lipid peroxidation analysis on basis of malondialdehyde (MDA) quantification, the tissues (liver and gills) were homogenized (1:3 weight: volume) in Tris HCl $0.1 \mathrm{M}, \mathrm{pH}$ 8.0. The prepared samples had to be analyzed on the same day.

\section{Biochemical analysis}

\section{EROD, GST, SOD, GPX, and CAT}

The EROD assay measures the O-dealkylation, mediated by CYP1A, of the non-fluorescent substrate 7-ethoxy-resorufin in resorufin, a fluorescent product detected by fluorometry $\left(\lambda_{\text {excit }}=537 \mathrm{~nm}, \lambda_{\text {emiss }}=583 \mathrm{~nm}\right)$ (Sarasquete and Segner 2000). The assay mixture contained potassium phosphate buffer 80 $\mathrm{mM}$ (pH 7.4), 7-ethoxyresorufin $3351 \mathrm{M}$, NADPH $20 \mathrm{mM}$ and microsomal liver extract (prepared sample). The reaction was observed $30^{\circ} \mathrm{C}$, for $3 \mathrm{~min}$. The EROD activity (pmol min${ }^{1} \mathrm{mg}^{-1}$ of protein) was calculated on the basis of a previously prepared resorufin standard curve.

GST activity was assessed according Keen et al. (1976). The assay mixture contained potassium phosphate buffer $0.2 \mathrm{M}, \mathrm{pH}$ 6.5, the substrate 1-chloro-2,4-dinitrobenzene (CDNB), GSH, and the sample containing GST. The activity was determined by measuring the absorbance at $340 \mathrm{~nm}$, on a spectrophotometer.

The method used to analyze SOD relied on a system that generated superoxide (xanthine/xanthine oxidase) coupled to cytochrome c reduction by the superoxide anion radical; this reaction intensified the absorbance at $550 \mathrm{~nm}$, at $25^{\circ} \mathrm{C}$. Addition of the sample containing SOD promotes an inhibition of cytochrome c reduction, because the enzyme competes with cytochrome c for superoxide (Mccord \& Fridovich, 1969).

GPx activity was measured according to Sies et al. (1979), by following the decrease in the absorbance at 340 $\mathrm{nm}$ on a spectrophotometer, due to the consumption of NADPH. Glutathione reductase (GR) used NADPH to reduce 
glutathione, previously oxidized by GPx during conversion of t-butyl peroxide-OOH to its corresponding alcohol.

CAT activity was measured by the method of Beutler (1975), through quantification of the rate of hydrogen peroxide decomposition, as evidenced by the decrease in absorbance at $240 \mathrm{~nm}$ at $30^{\circ} \mathrm{C}$.

Protein levels were determined by the method of Bradford (Bradford, 1976) in a microtube containing the sample and the Bradford reagent. After $40 \mathrm{~min}$ in the dark, the samples absorbance was read at $595 \mathrm{~nm}$. The protein concentration was calculated on the basis of the calibration curve prepared from bovine serum albumin (BSA) and the Bradford reagent.

\section{Lipid peroxidation}

Lipid peroxidation levels were measured on the basis of the product originating from the combination of malondialdehyde, a product of lipid peroxidation, and thiobarbituric acid (TBA), as analyzed by High Performance Liquid Chromatography (HPLC) and UV-Vis detection. TBA was dissolved in HCL $0.2 \mathrm{M}$, and the resulting solution was added to the homogenized sample. The reaction mixture was heated at $90{ }^{\circ} \mathrm{C}$, for $60 \mathrm{~min}$. The colored derivative was extracted with butanol and quantified by HPLC at $532 \mathrm{~nm}$, on the basis of a malondialdehyde (MDA) standard calibration curve that had been previously constructed by using the same procedure employed for the samples. The HPLC system consisted of an ESA584 pump and an ESA526 UV-Vis detector. The column was an ACE 5 C18 $\left(250 \_4.6 \mathrm{~mm}, 5 \mathrm{~lm}\right)$. The EZ Chrom Elite software (Agilent Technologies) was used to monitor the chromatograms and to identify quantify the peaks. The mobile phase consisted of $\mathrm{KH}_{2} \mathrm{PO}_{4}, 0.05 \mathrm{M}, \mathrm{pH} 7.0$, with $40 \%$ methanol, pumped at an isocratic flow of $1 \mathrm{~mL} \mathrm{~min}^{-1}$.

\section{Genotoxic and mutagenic analysis}

\section{Micronucleus test}

For the micronucleus test (Al-Sabti, 1986; Al-Sabti \& Metcalfe, 1995), a cardiac puncture was performed to remove 3 cc of blood from each animal. Three slides were prepared for each fish by means of the smear technique. The material was fixed in absolute methanol and stained by the Feulgen reaction. A total of 1000 erythrocytes were analyzed in each slide, which amounted to 3000 erythrocytes per fish. This analysis was conducted with the aid of an optical microscope, under $100 \mathrm{x}$ magnification. The frequency of micronuclei and nuclear abnormalities was calculated. Because all the cells in the field of view were counted, the total number of cells analyzed per animal may have varied. Hence, the total number of counted cells was transformed into a percentage of the numbers of micronuclei and abnormalities, and the frequency was measured as a percentage.

\section{Comet assay}

The comet assay was performed according to the method described by Singh et al. (1988). Blood samples were diluted in $1000 \mu \mathrm{L}$ of saline solution. Slides were prepared with 10 $\mathrm{uL}$ of this cell suspension and $120 \mu \mathrm{L}$ of low melting point agarose $(0.5 \%)$ at $37^{\circ} \mathrm{C}$. The slides were kept in a lysis solution $(1 \mathrm{~mL}$ of Triton X-100, $10 \mathrm{~mL}$ of DMSO and $89 \mathrm{~mL}$ of lysing stock solution, $\mathrm{pH} 10.0$ - stock solution: $\mathrm{NaCl} 2.5$ $\mathrm{M}$, EDTA100 mM, and Tris $10 \mathrm{mM}$ diluted to $1 \mathrm{~L}$ ) in the refrigerator for $1 \mathrm{~h}$. After lysis, the slides were placed on a horizontal electrophoresis box for $20 \mathrm{~min}$, at $25 \mathrm{~V}$, and 300 $\mathrm{mA}$. The slides were neutralized with Tris $0.4 \mathrm{M}(\mathrm{pH} 7.5)$ for $15 \mathrm{~min}$, and fixed in ethanol for $10 \mathrm{~min}$. The cells with no DNA damage migrated homogeneously. The cells with damaged DNA formed fragments of different sizes - the smaller ones migrated faster during electrophoresis, giving rise to a tail that resembled the tail of a comet.

Two slides were prepared from each fish. Fifty nucleoids were analyzed from each slide, according to the procedure described by Kobayashi et al. (1995). The slides were stained with ethidium bromide $\left(0.002 \mathrm{mg} \mathrm{mL}^{-1}\right)$. The analysis was conducted under a fluorescence microscope, filter B - 34 (excitation: $\lambda=$ $420-490 \mathrm{~nm}$, barrier $\lambda=520 \mathrm{~nm}$ ), under $40 \mathrm{x}$ magnification. The nucleoides were classified visually, according to the migration of the fragments: class 0 (no damage), class 1 (little damage), class 2 (medium damage), and class 3 (major damage). The injury score was calculated by multiplying the total number of cells in each class by the class value $(0-3)$.

\section{Morphological analysis}

\section{Hepatosomatic index (HSI)}

Fish were killed and their liver weight (LW) and body weight (BW) were recorded. The HSI for each fish was calculated by the formula: HSI $=[$ liver weight $(\mathrm{g}) /$ body weight $(\mathrm{g})] \mathrm{x} 100$.

\section{Statistical analysis}

To verify the effect of the herbicides on the animals, the treated fish were compared with control fish. The groups of small fish and large fish were analyzed separately. Tests for normality (Shapiro-Wilk) and homogeneity of variances (Levene) were applied. For the parametric data, one-way ANOVA was used, followed by the Tukey test. The KruskalWallis test for nonparametric data was used, followed by Multiple comparisons of mean ranks. Significant differences were accepted only when $p<0.05$. The analyses were performed using the software Statistica 7.0.

\section{RESULTS}

\section{Biochemical analysis}

Table 1 lists the biochemical parameters (EROD, GST, SOD, GPx, and CAT activities, and MDA levels). The activity of EROD, measured in the liver, differed in exposed fish as compared with the control fish. Small $O$. niloticus treated 
Table 1. Activities of the enzymes EROD (pmol/min/mp of protein), GST, SOD, GPx, and CAT (U/mg of protein), and MDA levels (nmol g-1 of tissue) in control fish and fish exposed to a mixture of the herbicides diuron and hexazinone at 125, 250, and $500 \mathrm{ug} \mathrm{L}^{-1}$ for $72 \mathrm{~h} . *$ indicates significant difference $(\mathrm{p}<$ 0.05 ) between the treatment and control groups.

\begin{tabular}{|c|c|c|c|c|c|c|c|c|}
\hline $\begin{array}{l}\text { Velpar } \\
\text { (ug L-1) }\end{array}$ & Fish size & Tissue & EROD & GST & SOD & GPx & CAT & MDA \\
\hline \multirow{3}{*}{0 (control) } & Small & Liver & $17.49+-7.78$ & $0.76+-0.29$ & $16.93+-4.34$ & $0.03+-0.00$ & $52.14+-17.95$ & $0.75+-0.18$ \\
\hline & & Gill & - & $0.16+-0.03$ & $15.00+-3.30$ & $0.03+-0.00$ & $11.94+-1.26$ & $0.96+-0.25$ \\
\hline & Large & Liver & $68.44+-64.71$ & $0.77+-0.11$ & $13.78+-5.35$ & $0.04+-0.00$ & $46.13+-12.33$ & $0.54+-0.16$ \\
\hline \multirow{5}{*}{125} & & Gill & - & $0.20+-0.04$ & $10.93+-1.03$ & $0.03+-0.00$ & $13.06+-1.49$ & $1.57+-1.10$ \\
\hline & Small & Liver & $44.35+-33.07$ & $0.61+-0.21$ & $15.06+-4.13$ & $0.02+-0.01$ & $34.23+-8.95$ & $0.66+-0.14$ \\
\hline & & Gill & - & $0.20+-0.05$ & $13.12+-3.50$ & $0.04+-0.01$ & $13.13+-4.31$ & $0.94+-0.16$ \\
\hline & Large & Liver & $66.92+-87.51$ & $0.67+-0.26$ & $15.07+-7.50$ & $0.03+-0.00$ & $43.75+-19.75$ & $0.47+-0.08$ \\
\hline & & Gill & - & $0.15+-0.04$ & $10.13+-1.31$ & $0.03+-0.00$ & $11.33+-1.44$ & $1.21+-0.29$ \\
\hline \multirow{3}{*}{250} & Small & Liver & $68.31+-23.47 *$ & $0.69+-0.11$ & $16.41+-4.54$ & $0.03+-0.00$ & $42.15+-9.05$ & $0.64+-0.17$ \\
\hline & & Gill & - & $0.21+-0.02$ & $9.20+-0.66$ * & $0.03+-0.00$ & $13.50+-2.22$ & $0.71+-0.15$ \\
\hline & Large & Liver & $20.63+-14.51$ & $0.661+-0.20$ & $13.79+-4.28$ & $0.03+-0.01$ & $36.35+-9.55$ & $0.65+-0.20$ \\
\hline \multirow{5}{*}{500} & & Gill & - & $0.14+-0.03$ & $11.54+-2.42$ & $0.03+-0.00$ & $12.44+-1.452$ & $1.70+-0.94$ \\
\hline & Small & Liver & $61.91+-27.34 *$ & $0.68+-0.26$ & $20.21+-5.02$ & $0.03+-0.01$ & $59.64+-19.81$ & $0.52+-0.16$ \\
\hline & & Gill & - & $0.20+-0.05$ & $10.46+-2.01$ & $0.03+-0.00$ & $13.92+-2.25$ & $1.13+-0.42$ \\
\hline & Large & Liver & $27.75+-10.87$ & $0.79+-0.22$ & $13.65+-3.70$ & $0.03+-0.00$ & $44.30+-20.29$ & $0.50+-0.11$ \\
\hline & & Gill & - & $0.15+-0.02$ & $10.74+-1.37$ & $0.02+-0.00$ & $13.61+-2.27$ & $1.07+-0.45$ \\
\hline
\end{tabular}

with commercial mixture at 250 and $500 \mathrm{ug} \mathrm{L}^{-1}$ showed higher EROD activity than the control group.

The activity of GST in the liver and gills of treated groups did not differ from the control group, in both small and large fish.

The activity of SOD in the livers of small fish treated with the commercial herbicides did not differ significantly from the activity of SOD observed in the control fish, as well as the activity of SOD in the livers of large fish.

In the gills, the activity of SOD in small fish exposed to the commercial herbicide mixture at $250 \mathrm{ug} \mathrm{L}^{-1}$ was lower than the activity of SOD in the control fish.

Regarding hepatic GPx activity, the treated animals (large and small) did not differ significantly from the control. GPx in the gills of the treated fish, both large and small, did not differ from the control.

CAT analysis did not reveal any significant differences in the liver and gills of small and large exposed fish as compared with the control.

Quantification of MDA, the product of lipid peroxidation, did not evidence any differences in the treated animals compared with the control, either in the liver or in the gills.

\section{Genotoxic and mutagenic analysis}

The micronucleous test performed on the blood of $O$. niloticus revealed just one cell with a micronucleous. Therefore, statistical analysis could not be performed (data not shown). However, nuclear abnormalities existed in the analyzed cells of all the studied groups, with no significant differences between exposed $O$. niloticus and control fish. The comet assay, performed on the blood of $O$. niloticus, did not show any differences between small fish and the control. However, large fish exposed to 125 and $500 \mathrm{ug} \mathrm{L}^{-1}$ of the mixture of diuron and hexazinone had more damage than the control. The results for nuclear abnormalities and the comet assay are shown in figure 2 .

\section{Morphological analysis}

The HSI, both in liver and gills, did not differ significantly in small and large exposed fish compared to the control (Fig. 3).

\section{DISCUSSION}

The mixture of herbicides diuron and hexazinone constitutes a selective herbicide for some plant species, because these compounds act by inhibiting photosystem II of photosynthesis. Unfortunately, several authors have reported that selective pesticides can damage non-target organisms (Freemark \& Boutin, 1995; Bony et al., 2008; Stephen et al., 2011). Although studies regarding the biological effects of pesticides have increased in recent years, there are no studies on the effects of the herbicide mixture diuron and hexazinone in biomarkers of $O$. niloticus.

The concentrations of Velpar K® WG used in present work were 125,250 and $500 \mathrm{ug} \mathrm{L}^{-1}$, which corresponds to diuron concentrations of 58.5, 117, and $234 \mathrm{ug} \mathrm{L}^{-1}$ and hexazinone concentrations of $16.5,33$ and $66 \mathrm{ug} \mathrm{L}^{-1}$ respectively. Lewis et al. (2009), showed, in the Great Barrier Reef, Australia, that diuron reached $20 \mathrm{ug} \mathrm{L}^{-1}$ and hexazinone reached $5 \mathrm{ug} \mathrm{\textrm {L } ^ { - 1 }}$ in sites were land use in the upstream catchment area is sugar cane cultivation (areas with $>10 \%$ sugar cane), and Miles \& Pfeuffer (1996), analyzing the surface waters of the canals of south Florida, United States, found the presence of diuron at a concentration of $76 \mathrm{ug} \mathrm{L}^{-1}$ and hexazinone at a concentration of $4.5 \mathrm{ug} \mathrm{L} \mathrm{L}^{-1}$. These data show that the amounts of the herbicides used in the present study are close to those found in the environment. 

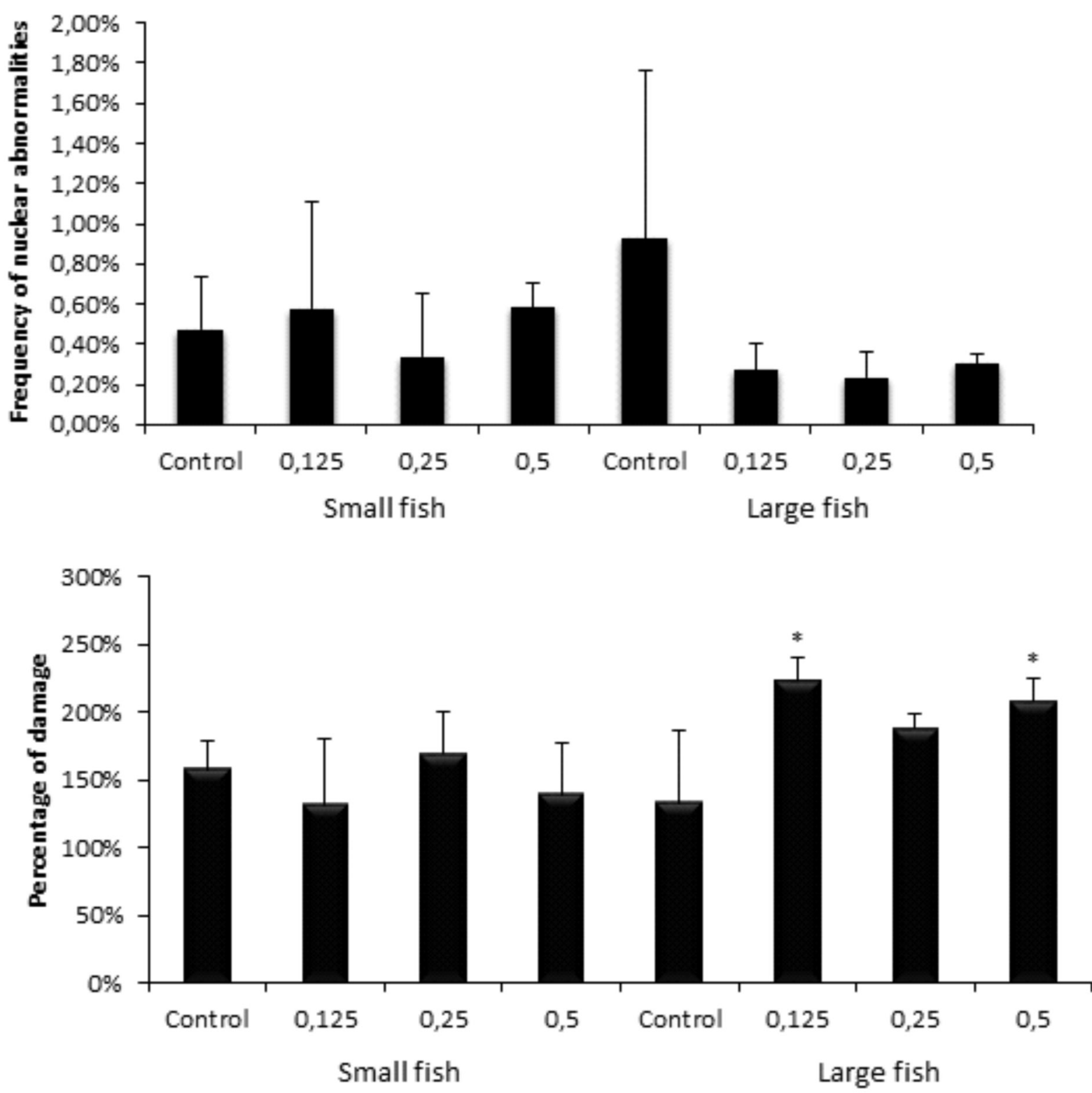

Fig 2. Genotoxic and mutagenic markers: Nuclear Abnormalities (A) and Comet Assay (B) on the blood of small and large O. niloticus exposed to tebuthiuron at concentrations of 125,250 , and $500 \mathrm{ug} \mathrm{L}^{-1}$ of a mixture of the herbicides diuron and hexazinone. $*$ indicates significant difference $(\mathrm{p}<0.05)$ between the treatment and control groups.

In this work, $O$. niloticus exposed to the mixture of the herbicides diuron and hexazinone, Velpar $\mathrm{K}{ }^{\circledR} \mathrm{WG}$, at 250 and $500 \mathrm{ug} \mathrm{L}^{-1}$ showed higher EROD activity than the control. Numerous studies have already demonstrated significantly increased hepatic CYP1A protein levels and activity in many fish species from polluted environments (Van Der Oost et al., 2003), and in fish exposed to herbicides, like alachor (Mikula et al., 2009). Furthermore, Schoket and Vincze (1990) analyzed Wistar rats treated intragastrically with diuron $\left(0.73,1.62,2.43\right.$, and $\left.3.65 \mathrm{mmol} \mathrm{kg}^{-1}\right)$ and chlorotoluron

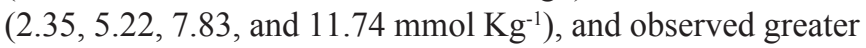
P450 monooxygenase activity, including EROD, for both herbicides. Rudzok et al. (2009) showed that diuron potently induced CYP1A1 mRNA transcription in HepG2 and elicited pronounced CYP1A1 enzyme activity when analyzed based on EROD activity. Therefore, our data are consistent with the results of these studies in that they reveal increased basal phase I biotransformation.

However, in the present work, there was no difference in the activity of GST in exposed fish as compared with the control. According to the Van Der Oost et al. (2003) and Andersson et al. (1985), compared with phase I systems, the induction responses of phase II enzymes are generally less pronounced, which may explain the induction of EROD, and the lack of response of GST in the present study.

Regarding antioxidant enzymes, higher SOD indicates increased $\mathrm{O}_{2}$-- production. In contrast, $\mathrm{O}_{2}$-- radicals, either in the form of radicals or after transformation to $\mathrm{H}_{2} \mathrm{O}_{2}$, can oxidize 


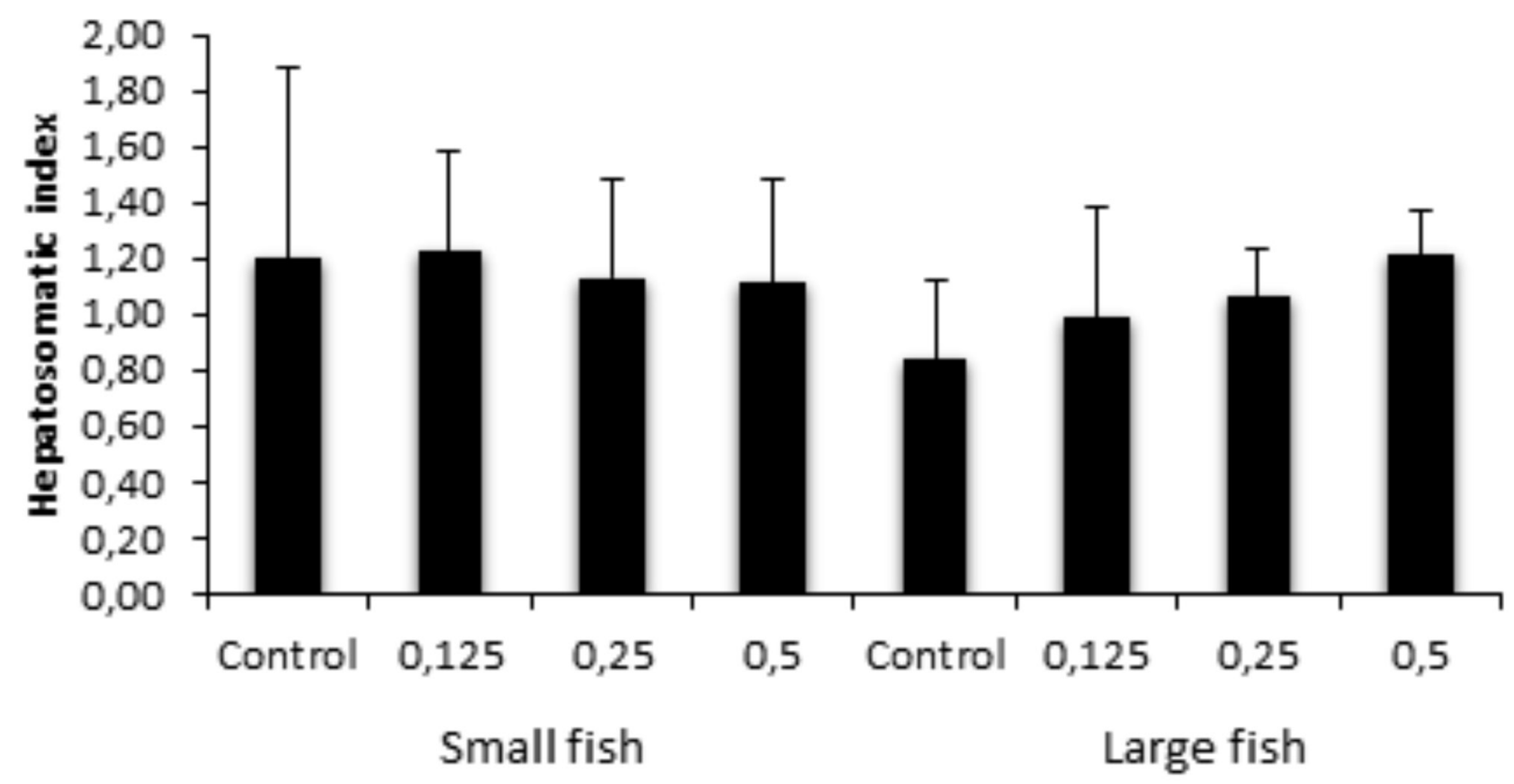

Fig 3. Hepatosomatic index in small and large O. niloticus exposed to a mixture of the herbicides diuron and hexazinone at 125, 250, and 500 ug $\mathrm{L}^{-1}$. * indicates significant difference $(\mathrm{p}<0.05)$

cysteine in the enzyme and reduce the level of SOD activity (Min \& Kang, 2008; Bartkowiak et al., 1981; Dimitrova et al., 1994). In this study, the activity of SOD in the gills of $O$. niloticus exposed to a mixture of diuron and hexazinone at 250 ug $\mathrm{L}^{-1}$ was lower than the activity of SOD in the control fish, which suggested oxidation in the SOD cysteine. In a study on $O$. niloticus exposed to sublethals concentrations ( 0.3 and $0.6 \mathrm{mg} \mathrm{L}^{-1}$ at 7, 14, and 21 days) of oxyfluorfen, Peixoto et al. (2006) observed significantly suppressed SOD activity in treated fish, as verified in the present work.

The activities of GPx and CAT in animals exposed to diuron and hexazinone did not differ from the control. Hence, there was no defense against oxidative stress at the tested concentrations. Similarly, Oruç \& Üner (2000) did not detect any difference in the activity of CAT in the liver of Oreochromis niloticus exposed to $27 \mathrm{ppm}$ of 2,4-D, indicating the absence of protection against oxidative stress.

The absence of protection against oxidative stress suggests no alteration in ROS production, which is consistent with the lack of lipidic peroxidation, as indicated by the MDA levels. Oruç \& Üner (2000) studied fish exposed to 27 ppm of 2,4-D for 24, 48, 72 , and $96 \mathrm{~h}$. These authors showed that exposure to the pesticide did not affect the MDA level in the liver of the fish. In the present study, it is probable that no oxidative stress occurred.

With respect to DNA damage, our results did not show the formation of micronuclei in the control or treated fish. Nuclear abnormalities did not differ significantly in exposed $O$. niloticus when compared with the control. However, the comet assay demonstrated significantly more damage in large animals exposed to a mixture of diuron and hexazinone at 125 and $500 \mathrm{ug} \mathrm{L^{-1 }}$ of diuron + hexazinone than in the control.
These data showed that the herbicide is genotoxic but not mutagenic. The absence of a significant increase in damage shown by the comet assay in fish exposed to $250 \mathrm{ug} \mathrm{L}^{-1}$ may be due to the low number of replicates. However, an experiment with more individuals would be not viable.

The micronucleus test and the comet assay conducted on various fish species exposed to a number of genotoxicants indicated that the micronucleus test was much less sensitive than the comet assay (Petras et al., 1995; Lee \& Steinert, 2003), which explains the damage indicated by the comet assay and the lack of damage indicated by the micronucleous test in the present work. Moretti et al. (2002) studied Terbutryn (up to 100 or $150 \mu \mathrm{g} \mathrm{mL}^{-1}$ ) in vitro using freshly isolated human peripheral blood leukocytes; they did not observe any significant increase in the number of micronuclei, but the comet assay evidenced DNA damage. The comet assay also identified a significant genotoxic effect of diuron on oyster spermatozoa exposed to the herbicide at concentrations higher than $0.05 \mu \mathrm{g} \mathrm{L}^{-1}$ (Akcha et al., 2012).

Analysis of HIS did not identify any differences between treated fish and the control, attesting that the herbicide mixture did not alter the liver morphology. Similarly, Mikula et al. (2009) studied Cyprinus carpio exposed to alachlor (42\% $\mathrm{w} / \mathrm{v})$ at $2400 \mu \mathrm{g} \mathrm{L}^{-1}$ and found no differences in HIS among the groups.

Analyzing the response of biochemical biomarkers in Nile tilapia, we can see that one of the biotransformation enzymes analyzed, EROD, indicated toxicity, as hypothesized. However, unlike what was expected, the study did not indicate the formation of reactive species, either by analysis of antioxidant enzymes or the formation of lipid peroxidation. 
This result may be because the Nile tilapia is a relatively resistant fish. However, Nile tilapia are widespread, including in Brazil, making it a suitable species for use as a biomarker. Moreover, if an animal considered resistant can do show alterations under exposure to a contaminant, we can be sure about this effect.

With respect to damage to the genetic material, as hypothesized, this study showed that the herbicide mixture induces damage at concentrations of 125 and $500 \mathrm{ug} / \mathrm{L}$ according to the comet assay. This test did not show a dosedependent induction, since fish exposed to $250 \mathrm{ug} / \mathrm{L}$ did not differ significantly from the control. This is probably due to the low number of replicas. It is possible that with a larger number of replicas, effects might be observed at a concentration of 250 ug/L, but an experiment with a larger number of individuals would not be viable.

Regarding the morphological parameters, the results did not show any changes in the liver morphology, as was expected. This may be have been due to the abovementioned resistance of Nile tilapia.

The present study also compared the number of biomarkers that responded to exposure of small and large fish to the herbicide mixture. In this context, the biomarkers EROD (liver) and SOD (gills) were changed in small fish as compared with the control. Therefore, the herbicide mixture affected the biochemical biomarkers in small fish more than in large ones, indicating that small $O$. niloticus were more responsive to the mixture of diuron and hexazinone than large fish regarding, in terms of biochemical biomarkers, which represent the first line of metabolic response of cells to the contaminants. Biochemical biomarkers varied more widely in small fish probably because of the higher metabolic activity in these individuals as compared with large fish (Kanak et al., 2014).

Regarding the genetic biomarkers, the present work showed that the herbicide mixture induced more DNA damage in large fish than in small ones, indicating that large fish are more responsive to genetic biomarkers.

Previous studies by our group (Franco-Bernardes et al., 2014) showed similar data for Nile Tilapia exposed to the herbicide tebuthiuron, and so did a study by Kanak et al. (2014), in which the authors exposed this species to metal using antioxidant parameters. Both studies revealed greater responsiveness in small fish, corroborating the results of our work.

\section{CONCLUSIONS}

In conclusion, this study shows that at the concentrations and exposure times tested, despite the absence of induction of reactive species and changes in morphology of the liver, the induction of EROD and genotoxic damage in Nile tilapia, a relatively resistant fish, indicates that the mixture of the herbicides diuron and tebuthiuron, Velpar $\mathrm{K} \circledR \mathrm{WG}$ is toxic to aquatic organisms. Moreover, small fish are more susceptible to biochemical biomarkers, which represent a first line of metabolic responses of cells to the contaminants. This shows that small fish are more susceptible to the herbicide mixture. However, large fish are more susceptible to genotoxic damage, and represents a better model for use in genetic damage studies.

\section{ACKNOWLEDGEMENTS}

Fundação de Amparo à Pesquisa do Estado de São Paulo - FAPESP (2010/04028-9) provided financial support for this project. The opinions, assumptions, and conclusions expressed in this material are those of the authors and do not necessarily reflect the views of FAPESP.

\section{CONFLICT OF INTERESTS}

There are no conflicts of interest.

\section{REFERENCES}

ABASS, K., REPONEN, P., TURPEINEN, M., JALONEN, J., PELKONEN, O. 2007. Characterization of Diuron $N$-Demethylation by Mammalian Hepatic Microsomes and cDNA-Expressed Human Cytochrome P450 Enzymes. Drug Metabolism and Disposition, 35:1634-1641. http://dx.doi. org/10.1124/dmd.107.016295

AKCHA, F., SPAGNOL, C., ROUXEL, J. 2012. Genotoxicity of diuron and glyphosate in oyster spermatozoa and embryos. Aquatic Toxicology, 106-107:104-113. http://dx.doi.org/ 10.1016/j.aquatox.2011.10.018

A1-SABTI, K. 1986. Comparative micronucleated erythrocyte cell induction in three cyprinids by five carcinogenic-mutagenic chemicals. Cytobios, 47:147-154

AL-SABTI, K., METCALFE, C. D. 1995. Fish micronuclei for assessing genotoxicity in water. Mutation Research, 343:121135. http://dx.doi.org/1016/0165-1218(95)90078-0

ALTINOK, I., CAPKIN, E., BORAN, H. 2012. Mutagenic, genotoxic and enzyme inhibitory effects of carbosulfan in rainbow trout Oncorhynchus mykiss. Pesticide Biochemistry and Physiology, 102:61-67. http://dx.doi.org/10.1016/j.pestbp.2011.10.011

ALVES, S. A., FERREIRA, T. C. R., SABATINI, N. S., TRIENTINI, A. C. A., MIGLIORINI, F. L., BALDAN, M. R., FERREIRA, N. G., LANZA, M. R. V. 2012. A comparative study of the electrochemical oxidation of the herbicide tebuthiuron using boron-doped diamond electrodes. Chemosphere, 88:155-160. http://dx.doi.org/10.1016/j.chemosphere.2012.02.042

ANDERSSON, T., PESONEN, M., JOHANSSON, C. 1985. Differential induction of cytochrome P-450-dependent monooxygenase, epoxide hydrolase, glutathione transferase and UDP glucuronosyl transferase activities in the liver of rainbow trout by b-naphthoflavone or Clophen A50. Biochemical Pharmacology. 34:3309-3314. http://dx.doi.org/10.1016/j. etap.2009.06.005

AYLLON, F., GARCIA-VAZQUEZ, E. 2001. Micronuclei and other nuclear lesions as genotoxicity indicators in rainbow trout Oncorhynchus mykiss. Ecotoxicology and Environmental Safety 49:221-225. http://dx.doi.org/10.1006/eesa.2001.2065

BARBASH, J. E., THELIN, J. P., KOLPIN, D.W., GILLIOM, R. J. 2001. Major herbicides in ground water: results from the national water-quality assessment. Journal of Environmenatal Quality 30:831-845. USGS Staff -- Published Research. Paper 27. http:// digitalcommons.unl.edu/usgsstaffpub/27. http://digitalcommons. 
unl.edu/cgi/viewcontent.cgi $?$ article $=1018 \&$ context $=$ usgsstaffp ub Accessed 19 sep 2014.

BARTKOWIAK, A., GRZELINSKA, E., VARGA, I. S., LEWKO, W. 1981. Studies on superoxide dismutase from cod (Gadus morhua) liver. International Journal of Biochemestry, 13:10391042. http://dx.doi.org/10.1016/0020-711X(81)90011-2

BENITEZ, J. F., REAL, F. J., ACERO, J. L., GARCIA, C. 2006. Photochemical oxidation processes for the elimination of phenylurea herbicides in Waters. Journal of Hazardous Materials B138:278-287. http://dx.doi.org/10.1016/j.jhazmat.2006.05.077

BEUTLER, E. 1975. Red Cell Metabolism: A Manual of Biochemical Methods. New York.

BICALHO, S. T. T., LANGENBACH, T., RODRIGUES, R. R., CORREIA, F.V., HAGLER, A. N., MATAllo, M. B., LUCHINI, L.C. 2010. Herbicide distribution in soils of a riparian forest and neighboring sugar cane field. Geoderma, 158:392397. http://dx.doi.org/ 10.1016/j.geoderma.2010.06.008

BONY, S., GILLET, C., BOUCHEZ, A., MARGOUM, C., DEVAUX, A. 2008. Genotoxic pressure of vineyard pesticides in fish: Field and mesocosm surveys. Aquatic Toxicology, http:// dx.doi.org/89:197-203. doi:10.1016/j.aquatox.2008.06.017

BORTOlETTO, F. S., TROMBETA, N. C., NEVES, E. M. 2009. Agricultural chemicals in Brazil: growth rate and relative demand by herbicides 1999-2008. Escola Superior de

Agricultura Luiz de Queiroz (ESALQ) and Universidade de São Paulo (USP).

$<$ http://www.usp.br/siicusp/Resumos/17Siicusp/resumos/2456.pdf $>$. https://uspdigital.usp.br/siicusp/cdOnlineTrabalhoVisualizarResum o? numeroInscricaoTrabalho $=2456 \&$ numeroEdicao $=17$ Acessed 20 sep 2014.

BRADFORD, M. M. 1976. A rapid and sensitive method for the quantitation of microgram quantities of protein utilising the principle of proteindye binding assay. Analytical Biochemistry, 72:248-254. http://dx.doi.org/10.1016/0003-2697(76)90527-3

CABRERA, L. C., CALDAS, S. S., RODRIGUES, S., BIANCHINI, A., DUARTE, F.A., PRIMEL, E. G. 2010. Degradation of Herbicide Diuron in Water Employing the $\mathrm{Fe}^{0} / \mathrm{H}_{2} \mathrm{O}_{2}$ System. Journal of the Brazilian Chemical Society, 21:2347-2352. http:// dx.doi.org/10.1590/S0103-50532010001200023

ÇAVAS, T., KÖNEN, S. 2007. Detection of cytogenetic and DNA damage in peripheral erythrocytes of goldfish (Carassius auratus) exposed to a glyphosate formulation using the micronucleus test and the comet assay. Mutagenesis, 22:263-268. http://dx.doi. org/10.1093/mutage/gem012

CAVALCANTE, D. G. S. M., MARTINEZ, C. B. R., SOFIA, S. H. 2008. Genotoxic effects of Roundup ${ }^{\circledR}$ on the fish Prochilodus lineatus. Mutation Research, 655:41-46. http://dx.doi. org/10.1016/j.mrgentox.2008.06.010

DIMITROVA, M. S. T., TSINOVA, V., VELCHEVA, V. 1994. Combined effect of zinc and lead on the hepatic superoxide dismutase-catalase system in carp (Cyprinus carpio). Comparative Biochemestry and Physiology, 108C (1):43-46. http://dx.doi.org/10.1016/1367-8280(94)90087-6

FISHER, S. W. 1991. Changes in the toxicity of the three pesticides as a function of environmental $\mathrm{pH}$ and temperature. Bulletin of Environmental Contamination and Toxicology 46:197-202. http://download.springer. $\mathrm{com} / \mathrm{static} / \mathrm{pdf} / 902 / \mathrm{art} \% 253 \mathrm{~A} 10.1007 \% 252 \mathrm{FBF} 01691937$. pdf?auth66=1411572913_d77de0580af42dbd5b801ae047b6e30 a\&ext=.pdf Accesse 10 sep 2014.

FRANCO-BERNARDES, M. F., MASCHIO, L. R., AZEREDOOLIVEIRA, M. T. V., ALMEIDA, E. A. 2014. Biochemical and genotoxic effects of a commercial formulation of the herbicide tebuthiuron in Oreochromis niloticus of different sizes. Ecotoxicolical and Environmental Contamination, 9(1):59-67. http://dx.doi.org/10.5132/eec.2014.01.008.

FREEMARK, K., BOUTIN, C. 1995. Impacts of agricultural herbicide use on terrestrial

wildlife in temperate landscapes: a review with special reference to North

America, Agriculture, Ecosystems \& Environment, 52:67-91. http:// dx.doi.org/10.1016/0167-8809(94)00534-L

Freitas Jr, 2012. Uso de defensivos é intensificado no Brasil. Sindicato nacional da indústria de Produtos para defesa agrícola SINDAG -. $\quad$ http://www.sindiveg.org.br/noticiaonline.php?cod=2278 Acessed 16 sep 2014.

KANAK, E. G., DOGAN, Z., EROGLU, A., ATLI, G., CANLI, M. 2014. Effects of fish size on the response of antioxidant systems of Oreochromis niloticus following metal exposures. Fish Physiolgy and Biochemistry, 40:1083-1091. http://dx.doi. org/10.1007/s10695-014-9907-x

KEEN, J. H., HABIG, W. H., JAKOBY, W. B. 1976. Mechanism for the several activities of the glutathione S-transferases. Journal of Biological Chemistry, 251:6183-8. http://www.jbc.org/ content/251/20/6183.full.pdf Acessed 22 sep 2014.

KOBAYASHI, H., SUGIYAMA, C., MORIKAMA, Y., HAYASHI, M., SOFUNI, T. 1995. A comparison between manual microscopic analysis and computerized image analysis in the cell gel electrophoresis. MMS Communication, 3:103-115.

LEE, R. F., STEINERT, S. 2003. Use of the single cell gel electrophoresis/comet assay for detecting DNA damage in aquatic (marine and freshwater) animals. Mutation Research, 544 (2003) 43-64. http://dx.doi.org/10.1016/S1383-5742(03)00017-6

LEWIS, S. E., BRODIE, J.E., BAINBRIDGE, Z.T., ROHDE, K., DAVIS, A., MASTERS, B., MAUGHAN, M., DEVLIN, M., MUELLER, J., SCHAFFELKE, B. 2009. Herbicides: a new threat to the Great Barrier Reef. Environmental Pollution, 157:2470-2484. http://dx.doi.org/10.1016/j.envpol.2009.03.006

LEWIS, S. E., SCHAFFELKE, B., SHAW, M., BAINBRIDGE, Z.T., ROHDE, K. W., KENNEDY, K., DAVIS, A. M., MASTERS, B. L., DEVLIN, M. J., MUELLER, J. F., BRODIE, J. E. 2012. Assessing the additive risks of PSII herbicide exposure to the Great Barrier Reef. Marine Pollution Bulletin, 65:280-291. http://dx.doi.org/10.1016/j.marpolbul.2011.11.009

MACKAY, D., SHIU, W. Y., MA, K.C. 1997. Illustrated Handbook of Physico-Chemical Properties and Environmental Fate for Organic Chemicals, vol. 5, N.Y.

MADHUM, Y. A., FREED, V. H. 1987. Degradation of the herbicides bromacil, diuron and chlortoluron in soil. Chemosphere, 16:1003-1011. http://dx.doi.org/10.1016/0045-6535(87)900373

MCCORD, J.M., FRIDOVICH, I. 1969. Superoxide dismutase. An enzymic function for erythrocuprein (hemocuprein), Journal of Biological Chemistry, 224:6049-55. http://www.jbc.org/ content/244/22/6049.full.pdf Acessed 19 sep 2014.

MEI, M., DU, Z., XU, R., CHEN, Y., ZHANG, H., QU, S. 2012. Photocatalytic degradation of hexazinone and its determination in water via UPLC-MS/MS. Journal of Hazardous Materials, 221222:100-108. http://dx.doi.org/10.1016/j.jhazmat.2012.04.018

MIKULA, P., BLAHOVA, J., KRUZIKOVA, K., HAVELKOVA, M., NEMETHOVA, D., HULAK, M., SVOBODOVA, Z. 2009. Effects of the herbicide LASSO MTX (alachlor $42 \% \mathrm{~W} / \mathrm{V}$ ) on biometric parameters and liver biomarkers in the common carp (Cyprinus carpio). Pesticide Biochemistry and Physiology, 93:13-17. http://dx.doi.org/10.1016/j.pestbp.2008.07.010

MIN, E.Y., KANG, J. 2008. Effect of waterborne benomyl on the hematological and antioxidant parameters of the Nile tilapia, Oreochromis niloticus. Pesticide Biochemistry and Physiology, 92:138-143. http://dx.doi.org/10.1016/j.pestbp.2008.07.007 
SARASQUETE, C., SEGNER, H. 2000. Cytochrome P4501A (CYP1A) in teleostean fishes. A review of immunohistochemical studies. Science of the Total Environment, 247:313-32. http:// dx.doi.org/10.1016/S0048-9697(99)00500-8

MORETTI, M., MARCARELLI, M., VILLARINI, M., FATIGONI, C., SCASSELLATI-SFORZOLINI, G., PASQUINI, R. 2002. In vitro testing for genotoxicity of the herbicide terbutryn: cytogenetic and primary DNA damage. Toxicology in Vitro, 16:81-88. http://dx.doi.org/ 10.1016/S0887-2333(01)00092-3

NWANI, C. D., NAGPURE, N. S., KUMAR, R., KUSHWAHA, B., KUMAR, P., LKRA, W. S. 2011. Mutagenic and genotoxic assessment of atrazine-based herbicide to freshwater fish Channa punctatus (Bloch) using micronucleus test and single cell gel electrophoresis. Environmental Toxicology and Pharmacology, 31:314-322. http://dx.doi.org/10.1016/j.etap.2010.12.001

ORUÇ, E. Ö., ÜNER, N. 2000. Combined effects of 2,4-D and azinphosmethyl on antioxidant enzymes and lipid peroxidation in liver of Oreochromis niloticus. Comparative Biochemistry and Physiology, Part C 127:291-296. http://dx.doi.org/10.1016/ S0742-8413(00)00159-6

PEIXOTO, F., ALVES-FERNANDES, D., SANTOS, D., FONTAÍNHAS-FERNANDES, A. 2006. Toxicological effects of oxyfluorfen on oxidative stress enzymes in tilapia Oreochromis niloticus. Pesticide Biochemistry and Physiology 85:91-96. http://dx.doi.org/10.1016/j.pestbp.2005.10.007

PETRAS, M., VRZOC, M., PANDRANGI, R., RALPH, S., PERRY, K. 1995. Biological monitoring of environmental genotoxicity in southwestern Ontario. In: Butterworth FM, Corkum LD, Guzman-Rincon J (Eds.), Biomonitors and Biomarkers as Indicators of Environmental Change, Plenum Press, New York, pp. 115-137.
RUDZOK, S., SCHMÜCKING, E., GRAEBSCH, C., HERBARTH, O., BAUER, M. 2009. The inducibility of human cytochrome P450 1A by environmental-relevant xenobiotics in the human hepatoma derived cell line HepG2. Environmental Toxicology and Pharmacology, 28:370-378. http://dx.doi.org/10.1016/j. etap.2009.06.005

SCHOKET, B., VINCZE, I. 1990. Dose-related induction of rat hepatic drugmetabolizing enzymes by diuron and chlorotoluron, two substituted phenylurea herbicides. Toxicology Letfers 50:17. http://dx.doi.org/10.1016/0378-4274(90)90246-I

SIES, H., KOCH, O. R., MARTINO, E., BOVERIS, A. 1979. Increased biliary glutathione disulfide release in chronically ethanol-treated rats, FEBS Letters 103 (1979) 287-90. http:// dx.doi.org/10.1016/0014-5793(79)81346-0

SINGH, N. P., MCCOY, M.T., TICE, R. R., SCHNEIDER, L. L. 1988. A simple technique for quantitation of low levels of DNA damage in individual cells. Experimental Cell Research, 175:184-191. http://dx.doi.org/10.1016/0014-4827(88)90265-0

VAN DER OOST, R., BEYER, J., VERMEULEN, N. P. E. 2003. Fish bioaccumulation and biomarkers in environmental risk assessment: a review. Environmental Toxicology and Pharmacology, 13:57-149. http://dx.doi.org/10.1016/S13826689(02)00126-6

WANG, X., WANG, H., TAN, C. 2005. Degradation and metabolism of hexazinone by two isolated bacterial strains from soil. Chemosphere, 61:1468-1474. http://dx.doi.org/10.1016/j. chemosphere.2005.04.116 